\title{
Using a One-Stop-Shop Concept to Guide Decisions when Single-Family Houses are renovated
}

\author{
Grøn Bjørneboe, Matilde; Svendsen, Svend ; Heller, Alfred
}

Published in:

Journal of Architectural Engineering

Link to article, DOI:

10.1061/(ASCE)AE.1943-5568.0000238

Publication date:

2017

Document Version

Peer reviewed version

Link back to DTU Orbit

Citation (APA):

Grøn Bjørneboe, M., Svendsen, S., \& Heller, A. (2017). Using a One-Stop-Shop Concept to Guide Decisions when Single-Family Houses are renovated. Journal of Architectural Engineering, 23(2).

https://doi.org/10.1061/(ASCE)AE.1943-5568.0000238

\section{General rights}

Copyright and moral rights for the publications made accessible in the public portal are retained by the authors and/or other copyright owners and it is a condition of accessing publications that users recognise and abide by the legal requirements associated with these rights.

- Users may download and print one copy of any publication from the public portal for the purpose of private study or research.

- You may not further distribute the material or use it for any profit-making activity or commercial gain

- You may freely distribute the URL identifying the publication in the public portal 


\title{
Case study: Using a One-Stop-Shop concept to guide decisions when single-family houses are renovated
}

Corresponding author:

Matilde Grøn Bjørneboe; Department of Civil Engineering, Technical University of Denmark, Brovej Building 118, DK2800 Kgs. Lyngby, DENMARK, matg@byg.dtu.dk

Co-authors:

Svend Svendsen; Department of Civil Engineering, Technical University of Denmark, Brovej Building 118, DK-2800 Kgs. Lyngby, DENMARK, ss@byg.dtu.dk

Alfred Heller; Department of Civil Engineering, Technical University of Denmark, Brovej Building 118, DK-2800 Kgs. Lyngby, DENMARK, alfh@byg.dtu.dk

\begin{abstract}
One way of reducing the use of fossil fuels in Denmark is to look into possible energy savings in the building stock, especially the large number of single-family houses from 1960-80. Energy renovation in this housing segment is progressing slowly.

The aim of this project was to find out how a One-Stop-Shop (OSS) or full-service concept could be used to guide the extensive energy renovation of single-family houses. The purpose was partly to identify the benefits and disadvantages of using the concept, and partly to evaluate its potential for increasing the degree of renovation. The scope of the project was to carry out renovations on up to three houses.

The project showed that the concept on its own was not enough to motivate the house owners to engage in extensive renovation. However, interviews with the house owners indicated that the renovation that took place had probably been expanded and improved due to the use of the concept, and that the renovation in general benefitted from an independent advisor.
\end{abstract}




\section{Introduction}

In Denmark, it is a political goal to reduce the use of fossil fuels to zero by the year 2050 (The Danish Government 2011). To achieve this, all electricity and heat supplied to buildings is to be based on renewable energy sources by 2035. The best solution for this is to find a balance between a sustainable energy supply and a reduced overall consumption.

One of the areas with the largest energy-saving potential in Denmark is single-family housing. In 2014, the total energy consumption, corrected with regard to climate, was $608 \mathrm{PJ}$, of which singlefamily houses accounted for 136 PJ, corresponding to 22\% (The Danish Energy Agency 2015). This is the largest single contributor apart from road transport.

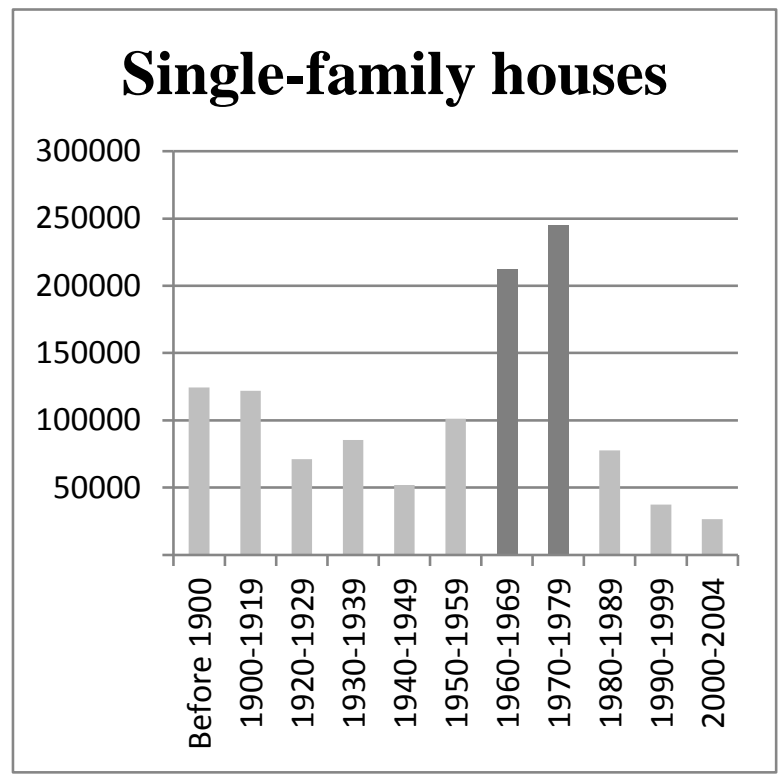

Fig. 1. Single-family houses in Denmark in 2014, shown by year of construction. Data from (Statistics Denmark 2014)

More than 450,000 single-family houses were built in Denmark in the period from 1960 to 1979 , see Fig. 1. It is very relevant to look at this segment of housing in connection with energy renovation because there are a lot of them, they are very similar in construction, many of them have high energy consumption, and many of them need renovation soon due to their age. The potential for achieving savings in this segment of the building stock is confirmed by the Danish Building Research Institute (SBi). In a report from 2004 (Wittchen and SBi 2004), they estimated the potential for reducing heat consumption in the Danish building stock on the basis of values from the Danish Building and Housing Register (BBR) and a database, which contains all Danish buildings that have received an energy label as part of the EPBD programme (Energy Performance of Buildings Directive). The study 
showed that the largest savings could be achieved in houses built before 1930 or in the standard houses of the 60 s due to their large number.

The renovation of single-family housing is proceeding very slowly. The market for single-family house renovation is dominated by do-it-yourself work and a craftsman-based approach (Tommerup et al. 2010). A survey of Danish house owners (Bolius 2016), showed that about 50\% seek the advice of craftsmen in connection with the maintenance of their houses, while only about $15 \%$ use professional advisors. A study of how Norwegian house owners think about energy renovation (Risholt and Berker 2013) showed the importance of craftsmen as advisors, and how good project management can help smooth the process, while a lack of knowledge is a barrier to reducing energy consumption.

This project is based on a One-Stop-Shop (OSS) concept, where the house owner is guided through the whole renovation process of their house, with a single contact person helping them. A number of projects has worked with the development and dissemination of OSS solutions. The project SuccessFamilies (2009-2012) aimed to change the business environment with the hope of speeding up the rate of sustainable renovations of single family houses, by creating full service concepts including e.g. technical solutions and financing services (Tommerup et al. 2010). An ERA-NET Eracobuild project One Stop Shop (2010-2012) tried to facilitate marked volume for extensive renovations of single family houses through a clustering of small and medium-sized enterprises (SMEs) thereby reducing the fragmentation of the renovation process (Haavik et al. 2012). The COHERENO project (2013-2016) aimed at developing a volume marked for renovation of single family houses to nearly zero energy buildings (nZEB), by strengthening the collaboration of enterprises e.g. in OSS partnerships in 5 countries (Straub 2016). Where the focus of these three projects where mostly on the business/professionals, this current case study investigates the OSS concept when applied to an actual renovation thereby enhancing the importance of the house owner/customer.

A group of researchers involved in the development of new business models for OSS solutions argue that when it comes to renovation, the decision-making process is a learning process for house owners, because they might not know what should or could be done (Haavik et al. 2010). When people are unaware of the potential for savings in their house, they will decide on maintenance and improvements based on their immediate needs or choose the cheapest solutions in the short term. Most people will not consider all relevant information, but rather be biased towards their initial starting point. In most cases the default option is preferred (Wilson and Dowlatabadi 2007). An analysis of the driving factors and obstacles for energy-efficient renovation of single-family houses in Switzerland (Jakob 2007), showed that only $7 \%$ of house owners intended to make comprehensive 
renovations and modernisations, while $72 \%$ were following a strategy of step-by-step renewal or continuous upgrading and $18 \%$ were carrying out no more than minimum maintenance. In Denmark, a survey of people who own single-family houses built in 1960-80 showed that, while many have started implementing small improvements (like new windows), very few have carried out larger renovations, such as insulation of the façade (Mortensen et al. 2015).

One way of removing these obstacles and encouraging renovation of the building stock would be to support the house owners in the decision-making process by making this process more structured and holistic (Galiotto et al. 2016). The idea is to focus on assisting the house owner in the process by looking at many different aspects of renovation not only energy, so as to encourage the house owner to choose the optimal renovation for their particular house. This current project also stresses the importance of assisting the house owner in the decision-making process. This assistance can ensure that the house owner's knowledge about the possibilities increases and that the renovation is relevant for the house and will save money in the long run. When uninformed customers do not demand energy conserving solutions, the initiative to inform must come from the building sector.

The most important factors influencing the decision making when it comes to large energy relevant investments was reviewed by (Kastner and Stern 2015). The focus was on owner-occupied semidetached or single family houses. They claim that this area is not yet sufficiently investigated, as the available research follows many different methods and cover a large area, which makes it difficult to draw strong statistical conclusions. One problem in particular is the focus on curtailment behavior (frequent actions, e.g. daily) where common behavioral models can apply. However even though energy relevant investments are linked to the daily life in the house, large investments are rare and follow another pattern more influenced by consequences than personal norms and habits. Even though lack of data prevented strong conclusions, one of the tentative conclusions they emphasize is the importance of receiving energy consulting from a reliable source, preferably face to face. Here the OSS-model has its strength, as the house owner receives relevant advice from the same source all through the project. The contact person will be able to emphasize the area's most important to the house owners, and thereby support the decision process.

An analysis of selected Belgian demonstration projects with respect to innovation and the experience of owner-occupants (Mlecnik et al. 2011) concludes that the development of an OSS solution might help to overcome some of the socio-technical obstacles that energy renovation of single-family houses faces today. Others have made the same point (Mahapatra et al. 2011, 2013) and argued that measures should be chosen based on their performance in holistic terms and with a longterm perspective. This project has the overall aim of making advice about extensive energy renovation 
more accessible by using an OSS solution. House owners who are fully informed about the ideal renovation of their house are more likely to choose an extensive renovation.

Vanhoutteghem describes a full-service renovation concept which includes all aspects of the renovation process, divided into 5 phases: initial evaluation, thorough analysis, proposal of package solutions, coordinated execution of the renovation, and finally quality assurance and continued commissioning of the house (Vanhoutteghem et al. 2011). These phases are somewhat similar to the 5 step innovation-decision process defined by (Rogers 1962, 1995) and adapted and applied to the building sector by (Mlecnik 2013) for analysing network activities with closed learning cycles. The 5 steps describe the whole decision process beginning with the person gaining knowledge about the possibilities, then a persuasion that this is a good idea followed by a decision to go on with the implementation of the concept ending with a confirmation whether it was good. An OSS concept as suggested by Vanhoutteghem et al. can follow the house owner through all five phases of the decision process. A comparison between Rogers model and the 5 phases defined by Vanhoutteghem is shown in Fig. 2. Firstly, the house owner must gain knowledge about the possibilities, which can be done by the OSS seeking out customers or alternatively by making an initial evaluation of houses available through policy. The persuasion can be gained through a thorough analysis of the house, followed by a decision regarding package solutions. The implementation is the coordinated execution of the renovation, and the confirmation is provided by quality assurance and continued commissioning. The link between the two models indicate that this type of OSS concept should be able to support the house owners through the whole decision-process, assuming that Rogers model applies for this type of decisions. The OSS concept suggested by Vanhoutteghem was used as the starting point for this project, in which it has been further developed and tested in real life.

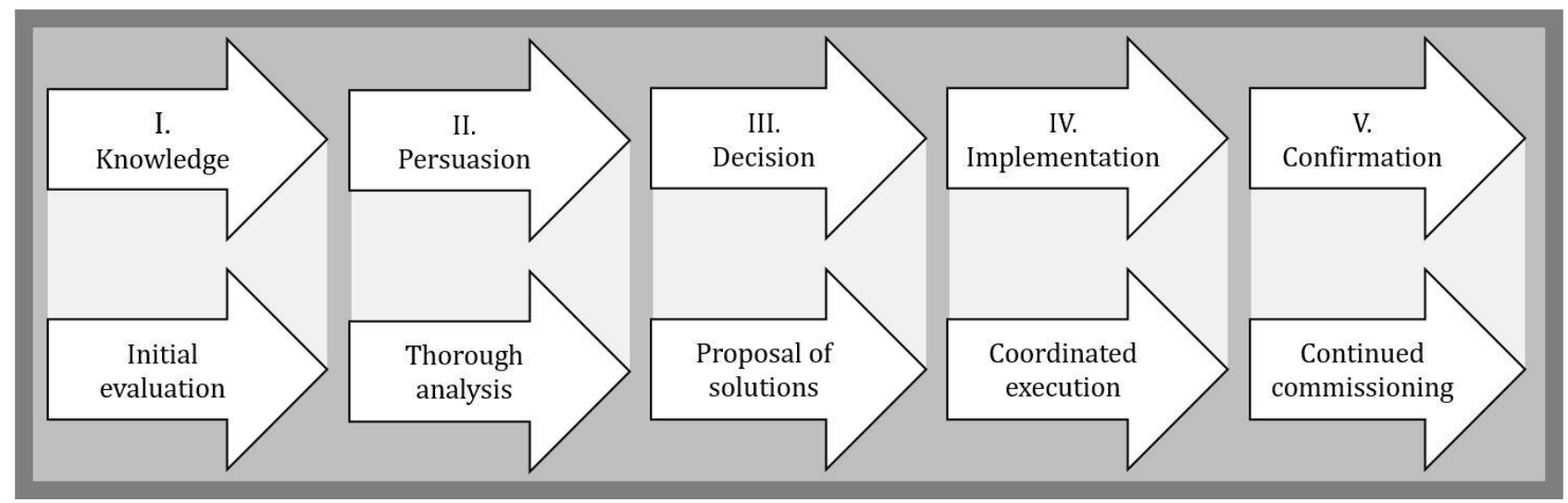

Fig. 2. A simplified version of the innovation decision process, originally by Rogers (Rogers 1995) compared to the 5 phases of the OSS concept as defined by Vanhoutteghem. Sources (Rogers 1995; Vanhoutteghem et al. 2011) 
According to a Danish survey (Bolius 2016), about 13\% of Danish house owners would see the offer of a One-Stop-Shop approach as a good reason for undertaking an energy renovation to their house, and in the younger segment (aged between 25 and 39), almost one in five would feel motivated by such an offer. Research on developing and identifying collaboration opportunities in renovation taking place in Denmark, Norway, Finland and Belgium (Mlecnik et al. 2012) used interviews and questionnaires to identify the needs of the supply side and to develop methods for creating a business model for OSS collaboration. This project focuses more on the receiving side and tests the concept in actual cases to cast further light on the relevance of the OSS concept.

A study on how to motivate private house owners to carry out renovations on their homes and how this is affected by policy (Gram-Hanssen 2014) concludes that most efforts to encourage energy renovation are based on this being a rational economic choice. However, the study points out that this is rarely the driving force when people decide to renovate. The economics only become significant when it comes to deciding the extent of the renovation. The OSS concept used in this project accommodates this observation by including the functional wishes of the house owner in the initial analysis of the house. The idea behind the holistic renovation concept is to make energy efficiency an integrated part of a total renovation, improving the house at many levels, not just in terms of energy use.

An empirical survey of homeowners in Germany (Stieß and Dunkelberg 2013) put particular emphasis on the link between homeowners and expert knowledge and concluded that a majority of homeowners are positive about using professional advisors who can help promote more ambitious and better energy improvements. However, there is a problem in that only those who are already aware of these benefits to some extent actually seek the advice of professional advisors. This project tries to meet this challenge too, because the OSS concept should appeal to people in general and make not just energy renovation but all kinds of home improvement more accessible.

\section{Method}

The study question of this work is how a One-stop-shop (OSS) concept influences the renovation of a typical Danish single family house, and whether the use can result in better and more extensive renovations.

The two most important prerequisites for this project were to find adequate, typical houses and the use of a One-Stop Shop (OSS).

For a house to be useful to this project, the owners had to be prepared to carry out an extensive renovation, they had to have the money to carry it out, and the house had to need renovation. The 
houses for the project were found using articles and advertisements in local newspapers. The houses were selected based on the following criteria:

- The type of house (single-family, not terraced houses or multi-storey buildings) witch had not received mayor renovation since it was build

- The amount of money the house owner was prepared to spend on the renovation - it had to be enough for an extensive renovation

- The age and layout of the house (only one floor, no basement or additional levels) - to best represent a large number of single-family houses in Denmark

- No slag used in the foundation of the house - slag can create problems for the stability of the house and may mean that renovation is not relevant.

- The estimated commitment of the house owner - among other things, the project would require the house owner to allow a number of measurements to be taken both before and after the renovation, and the active collaboration of the house owner would be crucial for the success of the project.

The timeframe was for the houses to undergo renovation within a year and a half, with the possibility of conducting measurements on the house for one year before and one year after the renovation.

The OSS had to have experience in the field of energy improvement, and be able to provide all the services necessary to the house owner, including counselling, calculations, planning, execution, and commissioning. The original OSS connected to the project was an independent company, allowing for the researcher to be an independent observer. However, due to changes in the circumstances during the project, the researchers had to participate in a more direct way, filling out the role of contact person for the house owner.

The planning and renovation process follows the 5 steps of a full-service renovation concept as was described by (Vanhoutteghem et al. 2011).

Step 1, the initial assessment was used to determine the scope and content of the renovation. Based on the wishes of the house owners, a proposal was drawn up by the OSS for their approval. To ensure that all relevant measures were considered, the planning included the following three areas, see Fig. 3: 
- Determination of the need for renovation based on the durability of the current building elements

- Determination of the desire for renovation based on the wishes of the house owners primarily for improved functions

- Determination of the possibility for energy improvements based on the current building elements and considering other possibilities.

DURABILITY

Estimating the remaining lifetime of the various building parts

- Roof

- Façade

- Windows and doors

- Floor and basement

- Installations

\section{FUNCTIONS} Clarifying the wishes of the house owner with regard to the functions of the house

- Establishing new windows in the roof

- Establishing new windows in the façade

- Changing the ceilling height

- Changes to existing room layout

- Extension of the house

- Improvement of existing functions (new bathroom, kitchen, utility room, etc )
ENERGY Including the relevant and beneficial energy improvements

- Investigate relevant solutions for all parts building elements (roof, façade, etc.)

- Connect improvements to renovations identified as necessary

- Aim to solve problems regarding indoor climate (temperatures, draughts, air quality, etc.)

\section{Fig. 3. Diagram showing the process for planning the renovation}

Step 2 was the thorough analysis. The house owner receives estimations of the energy balance of relevant solutions and economy based on estimated priced. Where there is doubt about which solution to choose, actual prices are collected for different options (in this case for thermal insulation), and the actual economy of the different suggestions are calculated, for the house owner to make an informed choice, which is Step 3.

Throughout the renovation, step 4, the house owner is to be kept informed about progress. When the renovation is complete, the result has to be verified in Step 5 and any errors rectified, to ensure the optimal effect of the improvements. 
Once the renovation is complete, the use of the OSS needs to be evaluated. This is done using pattern matching logic where an empirically based pattern (the outcome of the case study) are compared to a predicted one (Yin 2003). For the use of the OSS-concept to be a success, the following propositions should be true:

- The owner should have been informed about the best possible solution for their house

- The house owner should have been assisted through the decision-making process

- The house owner should have had only one contact person throughout the process

- The house owner should have had less administration due to the One Stop Shop

- The house should have received a relevant renovation, successfully upgrading the house

- The house should have a lower energy consumption than before the renovation

The evaluation of these propositions are mostly based on interview with the house owner, supported by measurements of energy consumption and experiences of the researchers and the building professionals.

\section{Limitations}

The scope of this article is limited to the use of OSS in the renovation process and the estimated effect OSS has had on the renovation. Detailed evaluation of the energy saving achieved is not within the scope. Due to the limited timeframe of the study, the focus was on houses where the house owner was already prepared to initiate an extensive renovation within a year and a half. Although a renovation plan spanning for many years also have some merits, it is not within the scope of this study.

There can be a number of issues connected with using a large sum on the renovation of a house, e.g. if the location of the house prevents it from getting a corresponding increase in value as a result. These issues are not within the scope of this study, and to avoid them only houses from areas with a reasonable demand was included. This was achieved by advertising for houses in local newspapers from the suburbs of Copenhagen. 


\section{Results}

\section{Locating participants}

After a process of advertising in local newspapers, about 40 house owners expressed an interest in being part of the project. The most relevant houses were selected using the criteria described above, see also Fig. 4, and three houses were selected. However, the owners of one house later turned out not to be able to afford the renovation after all, and had to leave the project.

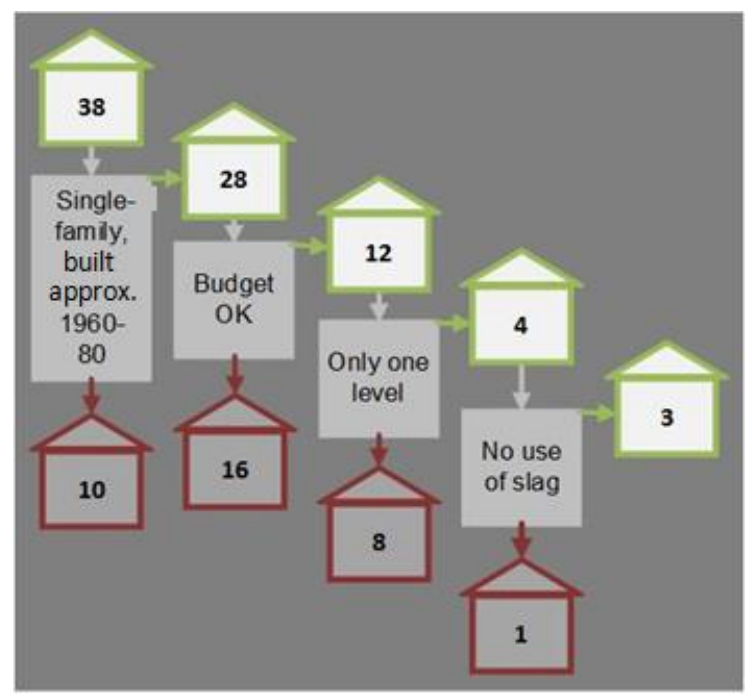

Fig. 4. The house selection process. Houses were discarded from the project if: they were terraced houses or multi-storey buildings; they were built long before or after the relevant period or had received significant improvements or renovation; the budget was less than 300,000 DKK (about 44,500 USD); they had a basement or first floor; or slag had been used under the floor. Of the 3 houses selected, one left due to bad economy.

\section{House A}

Area $160 \mathrm{~m}^{2}$

Built 1965

Energy consumption $205 \mathrm{kWh} / \mathrm{m}^{2}$ a year

Former work on the house

- $55 \mathrm{~m}^{2}$ extension in 1975

- Partly interior renovation in 1985
House B

Area $122 \mathrm{~m}^{2}$

Built 1981

Energy consumption $91 \mathrm{kWh} / \mathrm{m}^{2}$ a year

Former work on the house

$-10 \mathrm{~m}^{2}$ extension in 2004

Fig. 5. Basic facts about the two houses chosen as demonstration cases 
The remaining two representative single-family houses were therefore the test cases for testing the OSS concept for renovation. Fig. 5 shows the basic facts about the two houses.

At the time the project was initiated, there were no actual OSSs able to take on the task, because the concept was not common in the Danish building sector. However, it was possible to find a professional advisor who could be responsible for both the planning and execution of the renovation. In this way, he could provide a full-service solution for the house owner and act as an OSS contact.

\section{Initial analysis of houses}

The extent of the suggested renovation was determined taking into account both the durability of the existing building elements, the house owner's wishes for improved functionality, and the opportunities for implementing energy improvements.

The first step was to estimate the renovation requirements of the two houses based on the durability of the buildings. This was done by assessing the state of each house, and estimating the remaining service life of the various building elements.

In House A, the roof was close to the end of its service lifetime, and although it was still functional, it would need to be replaced within a few years. The windows and doors were still the originals and in need of replacement. The outer walls were masonry and in acceptable condition, with no need for replacement due to their durability. The original motivation for the house owner to start renovation was the need for a new roof.

House B was built more recently than House A, leaving a few years before its roof needed replacement. Most of the windows were the originals, and a few were punctured. Moreover, they were equipped with uninsulated ventilation hatches. The outer walls were masonry in good condition with no need for renovation due to their durability. The original motivation for the house owner to start renovation was the need for more space.

The second step was to implement the wishes of the house owners for improved functionality or other changes to the house, e.g. energy improvement, indoor climate and structural changes. These were specified by interviewing the house owners, ensuring they considered all relevant improvements as mentioned in Fig. 3. The improvements they wanted are shown in Fig. 6. The aim of identifying all their wishes was not necessarily to implement them during the renovation, but to make sure that the renovation prepared the house for these improvements. For example, a bathroom in House A would need to be renovated the near future. One of the existing two windows was to be replaced by wall. The planning of the new bathroom layout ensured that the right window was kept, which would not have been the case otherwise. 


\section{HOUSE OWNER'S WISHES \\ HOUSE A}

\section{Long-term functional improvements}

- Renovation of two bathrooms

- Renovation of utility room

- Installation of solar panels on the roof

Improvements to increase comfort and reduce energy consumption

- A new roof, possibly with better insulation

- Replacement of roof windows

- Extra insulation on façade walls if feasible

- Extra insulation under the floor in part of the house if feasible

- New windows with reduced heat loss

\section{HOUSE OWNER'S WISHES}

\section{HOUSE B}

\section{Functional improvements}

- New roof

- Raised ceiling to the roof in part of the house

- Extension of the house due to the need for an extra room

- Roof lights in dark corridor

- Changing part of the room layout

Fig. 6. List showing the house owners wishes for improvements in the two houses. The focus is on functional improvements, however specific wishes for energy improvements are also included.

Based on the renovation required by the building's condition and the wishes of the house owner, it was now possible to identify the beneficial energy improvements that should be considered in the two houses, see Fig. 7.

\section{ENERGY IMPROVEMENTS}

\section{HOUSE A}

- Extra insulation of the roof

- Extra insulation on the façade

- New windows and doors with a low Uvalue

- New mechanical ventilation

\section{ENERGY IMPROVEMENTS}

\section{HOUSE B}

- Extra roof insulation

- New windows with a low U-value

- Possibly extemal façade insulation

- New mechanical ventilation

Fig. 7. Suggested energy improvements for the two houses. 
In House A, it was decided not to install extra insulation under the floor, because this would be very costly and would not achieve energy savings that could justify the cost. If the renovation had included work on the floor for some other reason (new floors, floor heating, etc.), it would have been relevant to consider extra insulation under the floor, but as an energy-saving measure alone it was not found to be worthwhile.

\section{Extent of the renovation, House A}

With guidance from the OSS contact, the house owner decided to renovate the roof, façade, windows, doors and ventilation system.

The replacement of the roof made it possible to install extra insulation and make room for new ventilation pipes above the old ceiling. Since the old roof was being replaced, it was very beneficial to change the translucent part of the ceiling to actual light tunnels to reduce heat loss through these poorly insulated parts of the building envelope.

In connection with the new roof, a plan for the façade was prepared. If the house owner chose external insulation for the façade, the roof would require an extension of the overhang. To enable the house owner to make an informed choice, two solutions for external insulation (I and II) and a solution replacing the cavity wall insulation (III) were calculated and presented. The results are shown in Table 1.

Table 1. Solutions for insulation of the façade in House A.

\begin{tabular}{llcccc}
\hline & Type of solution & Energy saving & Investment & Payback period & CCE \\
& - & $\mathrm{kWh} / \mathrm{m} 2 \mathrm{a} \mathrm{year}^{\mathrm{a}}$ & $\mathrm{DKK}$ & Years & $\mathrm{DKK} / \mathrm{kWh}$ \\
\hline I & $\begin{array}{l}\text { External insulation, boards } \\
\text { II } \quad \begin{array}{l}\text { External insulation, } \\
\text { plastered }\end{array}\end{array}$ & 44.3 & 233,000 & 41 & 0.63 \\
III & 47.3 & 327,000 & 54 & 0.92 \\
\hline
\end{tabular}

Note: The energy savings were calculated using the program Be10. The investment was estimated using a pricelist in the program V\&S prisdata (Byggecentrum 2014). The payback period was calculated in accordance with the Danish Building Regulations (The Danish Transport and Construction Agency 2015). The CCE is the cost of conserved energy (the cost of saving $1 \mathrm{kWh}$ ) and was calculated using the method described in (Hansen and Vanhoutteghem 2012).

a The energy saving is $\mathrm{kWh} / \mathrm{m}^{2}$ total floor area every year. 
Solutions I and II yielded by far the best energy saving, estimated to about $44-47 \mathrm{kWh} / \mathrm{m}^{2}$ a year, while the cavity insulation, Solution III, provided a saving of only about $16 \mathrm{kWh} / \mathrm{m}^{2}$ a year. However, Solutions I and II would have been much more expensive than Solution III, and they had a longer payback period and a higher price per saved kWh (CCE). Despite a CCE that was lower than the cost of buying the energy $(1,11 \mathrm{DKK} / \mathrm{kWh}$ for this house in 2013, including electricity and gas for heating), the size of the investment combined with the more comprehensive implementation and a significant change to the visual exterior of the house, made the house owner choose Solution III: replacement of the cavity insulation.

To some extent, implementing the cavity insulation solution was independent of other improvements, but it could more advantageously be achieved after the windows and doors had been replaced, because removing them might cause the insulation to fall out. However, this improvement would replace the old cavity insulation that was inefficient, so it would be beneficial to implement it as soon as possible. Since the windows were approaching the end of their service life and their ability to maintain a good thermal indoor climate was poor, it was decided to include both replacement of the windows and the new cavity insulation in the current renovation.

During the renovation, the house would be given a new roof, new windows, new doors and new cavity insulation. All these would contribute to a reduction of infiltration, which is beneficial for the thermal indoor climate but critical for the atmospheric indoor climate if not addressed. To avoid creating a problem when the air change through the building envelope was reduced, it was decided to install a mechanical ventilation system with heat recovery in the house.

\section{Extent of the renovation, House B}

The owners of House B had many wishes for extensions and changes in room layout, because the house was getting too small for a family with 3 children. To get the best result, it was important to determine how the house would be extended before any large renovation was planned. Changing the functions of rooms could have a large influence on the building envelope and might for example require repositioning of windows and doors.

A proposal for the new layout of the house was made in collaboration with the OSS contact, who was an architect, see Fig. 8. If the living room was expanded with an extension of the building, part of the old living room could be made into a new children's room. Replacing a wall in the kitchen with a kitchen island would open up the space. The original entrance hall, which had been used as an office, could be made into a second bathroom. 


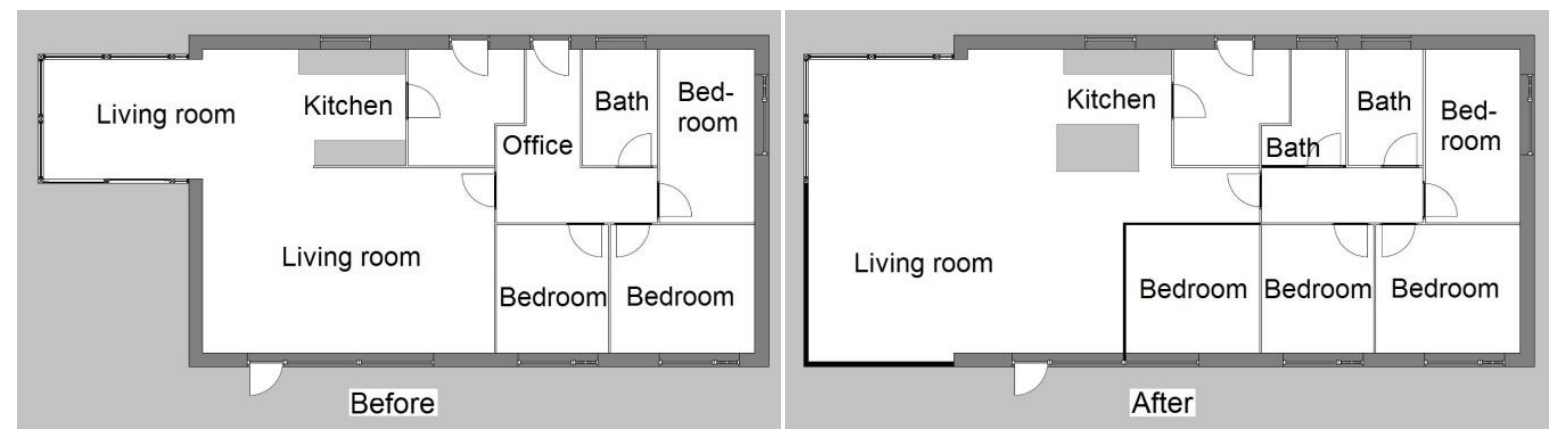

Fig. 8. Layout of House B before and after the suggested changes. The changes were: an extension expanding the living room; removal of the kitchen wall; an extra bedroom; an extra bathroom.

It was decided not to apply extra insulation to the façade, because the energy benefit would be small compared to the cost. The house already had cavity insulation so, as shown in Table 2, the energy saving would only be about $10-12 \mathrm{kWh} / \mathrm{m}^{2}$ a year, while the large investment would have a payback period of at least 164 years. The cost of conserved energy (CCE) was also very high, and from an economic point of view the cost of saving can in this case not compete with the cost of using the energy (about $0.8 \mathrm{DDK} / \mathrm{kWh}$ for this house in 2013, including gas for heating). When the CCE is higher than the energy price it is cheaper to use the energy than to save it.

Table 2. Possible energy improvements for House B.

\begin{tabular}{llccc}
\hline Type of solution & $\begin{array}{c}\text { Energy saving } \\
\mathrm{kWh} / \mathrm{m}^{2} \mathrm{a} \\
\text { year }\end{array}$ & DKK & Years & DKK/kWh \\
\hline A & External insulation, boards & 10.5 & 168,500 & 164 \\
B External insulation, plastered & 11.7 & 222,000 & 195 & 1.53 \\
\hline
\end{tabular}

Note: Solution A was external insulation covered with plates of e.g. metal or stone to protect the insulation from weather. Solution B was hard insulation boards covered with plaster to create a rain shield.

The renovation would, however, include a new roof, because the old one was at the end of its service life. In connection with this, the old vapour barrier would have to be replaced, because it was in poor condition, so extra insulation could be added to the ceiling. Moreover, the old windows would have to be replaced, and a mechanical ventilation system would be required to avoid problems with the indoor air quality when the other improvements had been implemented. 
In the end, the house owners chose not to go through with the renovation because the house would still not meet their functional needs. The extension and new room layout could have solved many problems, but they would no longer have an office, and the extension would remove some of the qualities they originally liked about the house. Instead of renovating, they decided to put their house up for sale, and find a new home that better suited their needs.

\section{Renovation of House A}

Before the renovation of House A, the project encountered an obstacle. The company which was supposed to carry out the renovation on behalf of the OSS went out of business due to lack of customers. This meant that the original contact person could not complete the project as intended, but had to be replaced halfway through the project by a new contact person and a new company to execute the renovation.

To carry out the renovation on which the owners of House A had decided, three quotations were requested from companies with experience in energy renovation. The estimated cost was similar for two of the offers but the third was much higher, see Table 3 . The prices were requested by researchers from DTU (Technical University of Denmark) acting as the new contact, based on the specifications prepared by the architect. The house owner selected Company B based on their strategy for the renovation, which included complete scaffolding over the house while replacing the roof.

Table 3. Collected prices for the renovation of House A.

\begin{tabular}{lccc}
\hline & Company A & Company B & Company C \\
& DKK & DKK & DKK \\
\hline Replacement of cavity insulation & 38,500 & 34,900 & 28,528 \\
New roof incl. light tunnels & 408,700 & 377,919 & 457,004 \\
$\begin{array}{l}\text { New doors and windows, mechanical } \\
\text { ventilation + other expenses }\end{array}$ & 236,000 & 273,814 & 484,215 \\
\hline In total & $\mathbf{6 8 3 , 2 0 0}$ & $\mathbf{6 8 6 , 6 3 3}$ & $\mathbf{9 6 9 , 7 4 7}$ \\
\hline
\end{tabular}

The renovation of the house was carried out in the summer of 2013, with Company B as contractor, see Fig. 9. To guide the house owner through the process, an independent site engineer was appointed to advise the house owner during the renovation. He also checked the work for faults and ensured that they were corrected during the building process. Meetings were held at the building site every week to ensure communication between the house owner, the advisers and the craftsmen. 

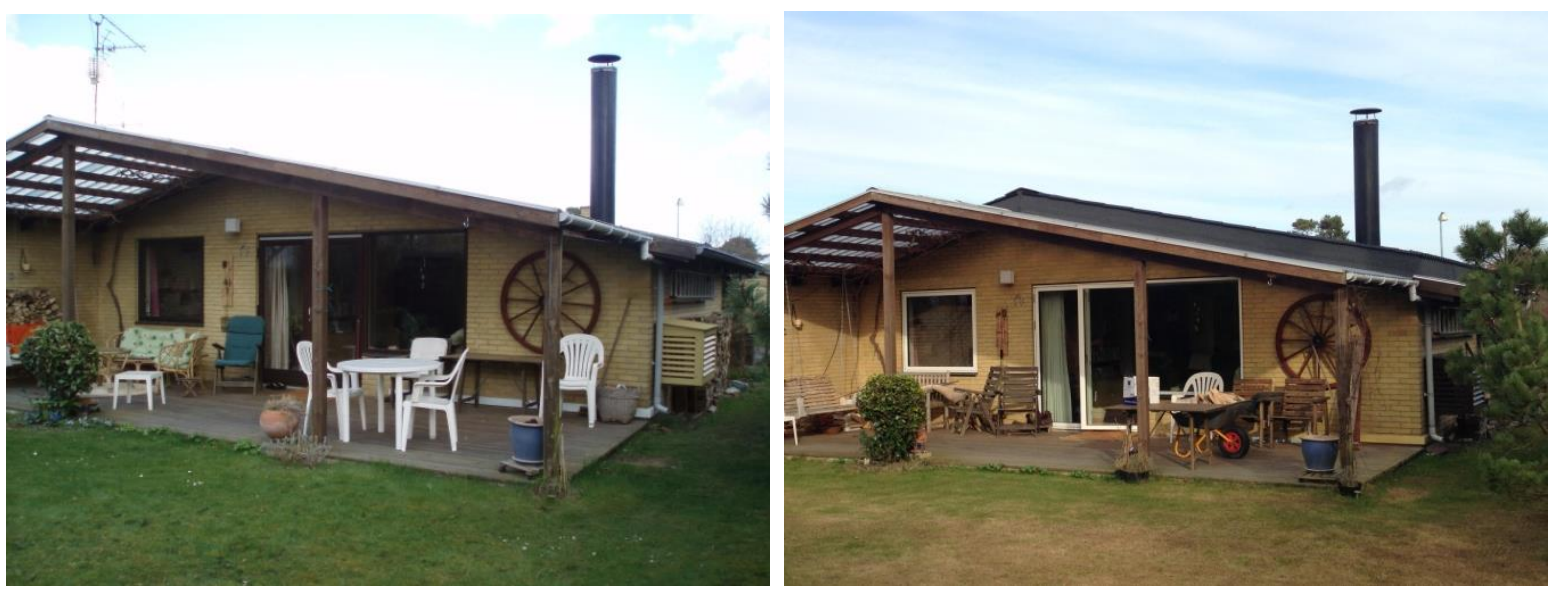

Fig. 9. House A before and after the renovation. Visible changes are the new windows and roof.

Table 4. The energy use of House A before and after the renovation.

\begin{tabular}{lcc}
\hline & $\begin{array}{c}\text { Measured on } \\
\text { house } \\
\text { Total energy use }\end{array}$ & $\begin{array}{c}\text { Model in Be10 } \\
\text { Energy used } \\
\text { for heating }\end{array}$ \\
\hline Energy consumption before renovation $\left(\mathrm{kWh} / \mathrm{m}^{2}\right.$ a year) & $173.3^{\mathrm{b}}$ & 216.5 \\
Energy consumption after the renovation $\left(\mathrm{kWh} / \mathrm{m}^{2}\right.$ a year) & $131.2^{\mathrm{c}}$ & 125.0 \\
Energy saving due to renovation $\left(\mathrm{kWh} / \mathrm{m}^{2}\right.$ a year) & 42.1 & 91.5 \\
Energy saving due to renovation $(\%)$ & 24.28 & 42.3 \\
\hline
\end{tabular}

Note: The measured and simulated energy consumption in $\mathrm{kWh} / \mathrm{m}^{2}$ a year should not be compared directly because they cover different things; the relevant comparison is between before and after.

${ }^{a}$ Total electricity use plus total gas consumption. This includes the use of hot water and electrical appliances, but since these factors would not change to any extent due to the renovation, the difference can still indicate the energy saving.

${ }^{\mathrm{b}}$ Total gas consumption for a year (May $1^{\text {st }} 2010$ - April $30^{\text {th }}$ 2011) with a conversion value of $11 \mathrm{kWh} / \mathrm{m}^{3}$ added to the total electrical consumption for the year divided by the heated area of $160 \mathrm{~m}^{2}$. The number is weighted according to climate using degree days.

${ }^{\mathrm{c}}$ Total gas consumption for a year (January 2nd 2014 - January 2nd 2015, half days included) with a conversion value of $11 \mathrm{kWh} / \mathrm{m}^{3}$ added to the total electrical consumption for the year divided by the heated area of $160 \mathrm{~m}^{2}$. The number is weighted according to climate using degree days. 
After the renovation was complete, the energy use of House A was measured and compared to the energy use before the renovation, see Table 4.

Calculations of the energy consumption were made in the program Be10 (SBi Danish Building Research Institute 2006; The Danish Transport and Construction Agency 2015), which is normally used to assess whether a building meets the requirements for energy consumption according to the Danish Building Regulations. The calculations showed that the energy consumption of the house was reduced by $91.5 \mathrm{kWh} / \mathrm{m}^{2}$ a year, or $42.3 \%$. This moved the house from Energy Label E to Label C on the Danish energy labelling scale (The Danish Energy Agency 2013). The measured saving was less, only about $24 \%$.

\section{Discussion}

The aim of the project was to test the effect of using the OSS concept to guide a real renovation of a single-family house. This sort of demonstration includes a large degree of uncertainty, because the process cannot be compared to a precise baseline. How much guidance the house owner would have received or how much they would have decided to renovate can only be estimated based on their own statements and an estimation of the average house owner. Even two houses that were similar when built would have different owners making it difficult to compare them directly.

Originally, the project should cover 3 renovations, enabling comparison of the results, even if the cases could be seen as individual case studies. However, only one renovation was completed making this a single-case study. Although it would have been beneficial with 3 or even 2 completed renovations, the study still has its merits as it is a representative case (Yin 2003).

The OSS concept is not yet common in the sector of renovation of single-family houses. This posed a challenge when it came to finding a company to guide the house owners through the process following the concept. The initial solution, where an adviser was chosen as contact person through his contact with relevant companies, did not work out in the end. The contact person was replaced by a researcher working as contact halfway through the process. The negative consequence of this was partly that the researchers were no longer only observing, and partly that the project then had an extra layer of coordination, because all services (architect, engineer, contractor) were detached from the OSS contact, and not integrated as originally planned. But since most of the contact to all these actors went through the new contact person, the effect of having an OSS was still maintained for the house owner, see Fig. 10. One benefit from this change in administration was that it gave the house owner an independent and impartial adviser. The house owner could now choose from multiple offers on the execution of the renovation, and the advisor was able to check the progress of the renovation on 
behalf of the house owner. The successful process of the renovation suggests that perhaps the answer is not to change the building industry towards OSS, but rather to enhance the role of the independent building advisor. Alternatively, the freedom to choose between different contractors should be included in the OSS, even when the contact person is more closely connected to one company. This could be achieved by making the initial planning free if the house owner decides to use the company, but also by making it possible to pay for the initial planning as an independent service as suggested in (Vanhoutteghem et al. 2011). Otherwise the initial planning should be removed from the OSS, and instead e.g. be a mandatory part of selling a house, as is currently the case for energy certificates in Denmark. By making it mandatory, all house owners would receive a plan providing knowledge about a possible renovation, which is the first step in the decision process according to (Rogers 1995), see also Fig. 2. By an estimation based on similar services, the initial plan for a house would cost the owner of a $150 \mathrm{~m}^{2}$ house about 12,500 DKK (about 1,900 USD) (Marxen and Knorborg 2011). Current policies in Denmark enables a tax reduction for 12,000 DKK for energy efficient improvements of houses including energy advice. This would help pay for a mandatory initial energy renovation plan.

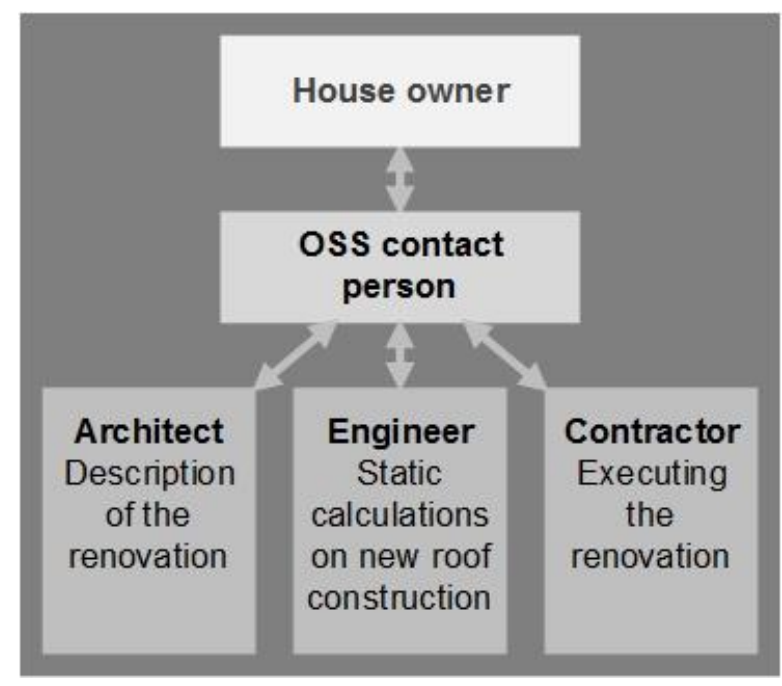

Fig. 10. Diagram showing the communication channels during the planning process of the renovation of House A. The main contact person for the house owner was DTU, who then contacted people with the necessary competence.

Despite the difficulties, a renovation was carried out using a form of the OSS concept. The house owners were successfully informed about the best solutions for their house, taking into account the current durability of existing building elements, their wishes for improved functions, and the possibilities for energy improvements. In the case of the façade, the house owners chose the least ambitious solution by only replacing the cavity insulation. However, this was the best solution economically, because the cavity insulation resulted in a much lower cost of conserved energy. The 
fact that people reject extensive measures like external insulation sets a limit to the savings that can be achieved in each house, which increases the number of houses that need to be renovated to reduce the total energy consumption sufficiently. However, ensuring that the house owners were informed about the possibilities means that lack of information is no longer an obstacle and increases the probability of extensive measures being implemented.

The house owner was kept informed on most aspects of the renovation, but this was very timeconsuming. The process would benefit from better presentation, making the information easily understandable and more visual. The process could be helped by having a checklist, catalogue or program presenting the options to the house owner in an easily accessible and visual way. The overview of things to consider shown in Fig. 4 is a good beginning, but should be extended with possible solutions or inspiration for the house owner to look at. Moreover, visualisation of the remaining lifetime of different building elements can help the house owner understand that the house requires maintenance to avoid greater expense later.

The owner of the renovated house was very much involved in the renovation in this project. The goal of achieving a significant reduction in the administration for the house owner was not met, at least in the planning process. However, the constant access to impartial advice was a great help, especially during the execution of the renovation. Having a building professional as representative for the house owner, checking the quality of the work during the process increased the satisfaction with the project according to the house owners. The close connection between the house owner and the contact also aided the discovery and rectification of errors in and after the building process, such as a new front door that was not tight and had to be replaced and a ventilation system that needed to be balanced more than once to achieve the optimal operation.

The renovation resulted in a better insulated house with a higher level of comfort. In general, the house owners were very pleased with both process and result, and they report that they can feel the effect of the renovation in terms of better air quality, less draught, and smaller temperature fluctuations. These observations were in compliance with measurements made in the house. In general, and if the OSS concept were to go large scale, it might be necessary with some form of independent party to make measurements to ensure the quality of the renovation.

As mentioned above, it can be difficult to determine the exact effect of the use of OSS on this project. Originally, the owners of House A did not have a large renovation in mind. They knew something had to be done about their roof, and because of its low slope it was not possible to just clean it. They knew that there might be a benefit in adding extra insulation when replacing the old roof. There is also a requirement in the Danish building regulations of the time (The Danish Ministry of Economic and Buiness Affairs 2010) for a maximum thermal transmittance of $0.15 \mathrm{~W} / \mathrm{m}^{2} \mathrm{~K}$ when 
a roof has been renovated. Before the renovation, the thermal transmittance of the roof was about $0.41 \mathrm{~W} / \mathrm{m}^{2} \mathrm{~K}$, which was reduced to about $0.08 \mathrm{~W} / \mathrm{m}^{2} \mathrm{~K}$, considerably better than required by the building regulations at the time of the renovation. Moreover, the cavity walls received new insulation, the windows and doors were replaced, and a ventilation system with heat recovery was installed. Whether some or all of these improvements would have been implemented without the OSS guidance cannot be determined conclusively. But it seems very unlikely that the owners would have installed ventilation if they had just approached a company asking for a new roof.

The renovation measures were successfully implemented. However, the measured saving of $24 \%$ was less than expected in view of the simulation in which savings of $42 \%$ were found. The numbers cannot be compared directly because electricity for light and appliances was not included in the simulation, but the difference was also due to other factors:

- Uncertainty about the mutual contribution from the four different heat sources in the house (gas boiler, electric convector, heat pump, and wood burning stove)

- The wood burning stove was not included in the simulation

- Simulation conditions do not reflect actual conditions

- Changes in user behaviour with increased comfort after renovation

Although the saving was less than initially expected, the house has still achieved a significant reduction in the total energy consumption.

One of the aims of this project was to test how the use of an OSS could motivate house owners to undertake better renovations on a larger scale. However, the owners of two of the houses chose to leave the project, so only one out of three houses underwent the planned renovation. This suggests that the use of the OSS concept alone is not enough to motivate people to undertake extensive renovations. The goal of a OSS with some marked volume is to make renovation more accessible to many house owners, including those who do not have great interest in the subject to begin with. The house owners participating in the project must be considered as already having a certain interest in a more energy efficient home to begin with, or they would not have applied for a place in the project. Despite this, the drop out rate was high. The OSS might still work as a motivator, but it is unlikely that the concept on its own will solve the problem of the slow progress of renovating the existing building stock. 


\section{Conclusion}

The purpose of this project was to determine benefits and disadvantages when using OSS, and to see if the use of OSS could improve specific renovations.

The initial advising of the house owners enabled them to make informed choices about the extent of the renovation. This process brought benefits in terms of less uncertainty and better long term solutions, but was very time-consuming. There is a need to create tools to make the process more effective. The tools or checklists should ensure that house owners are aware of all the options and the urgency of certain improvements - all presented in an easily accessible and visual way.

The involvement of one single contact person did not work out as planned. However, the independent advisor proved to be a benefit for the house owners, who became free to choose their contractors and received an impartial check of the work during the renovation.

It is not possible to determine the level of renovation the house owners would have chosen had they not participated in this project where the OSS concept was used to inform and guide them. However, interviews with the house owners and knowledge of the usual procedure suggest that the house received a more extensive renovation than would otherwise have been the case, even though not all proposals were implemented. The energy consumption of the house was reduced by more than $25 \%$, and the house owners report an increase in comfort and air quality.

Since the house was successfully renovated with a satisfactory result, the use of the OSS concept was a success. However, the fact that in two out of three cases house owners decided to leave the project without renovating puts into question whether the concept would be useful on a larger scale in motivating more people to renovate their houses. It might ensure better renovations for those already interested in the renovation, but may not be able to motivate those still in doubt.

\section{Acknowledgements}

This research was supported by the Energy Technology Development and Demonstration Program (EUDP) through the project EUDP 2009-II, aimed at the development and demonstration of system solutions for renovating the building envelope of existing single-family houses. Thanks to all the project partners who participated in this project and contributed with their knowledge. Thanks also to the craftsmen and advisors who participated in this project. A special thank-you to the owners of the houses who chose to participate in this project. Without their collaboration, it would not have been possible. 


\section{References}

Bolius. (2016). "Boligejeranalyse 2016."

Byggecentrum. (2014). "Velkommen til V\&S Prisdata." V\&S prisdata [Price Data] (in Danish), <http://www.byggecentrum.dk/produktadgang/vs-prisdata-startside/>.

The Danish Energy Agency. (2013). Energimarkningsskala for en- og flerfamiliehuse pr. 8. september 2013 (in Danish).

The Danish Energy Agency. (2015). Energistatistik 2014 (in Danish).

The Danish Government. (2011). Our future energy.

The Danish Ministry of Economic and Buiness Affairs. (2010). Danish Building Regulations (BR10). The Danish Ministry of Economic and Business Affairs \& Danish Enterprise and Construction Authority.

The Danish Transport and Construction Agency. (2015). Danish Building Regulations 2015 (BR15).

Galiotto, N., Ph, D., Heiselberg, P., and Knudstrup, M. (2016). "Integrated Renovation Process : Overcoming Barriers to Sustainable Renovation." Journal of Architectural Engineering, 22.

Gram-Hanssen, K. (2014). "Existing buildings - Users, renovations and energy policy.” Renewable Energy, Elsevier, 61, 136-140.

Hansen, S., and Vanhoutteghem, L. (2012). "A method for economic optimization of energy performance and indoor environment in the design of sustainable buildings." Proceedings of the 5th International Building Physics Conference, Kyoto Univercity, 741-747.

Haavik, T., Tommerup, H. M., Vanhoutteghem, L., Svendsen, S., Paiho, S., Ala-juusela, M., Mahapatra, K., Gustavsson, L., and Aabrekk, S. (2010). "Renovation of Single-Family Houses - An Emerging Market." Proceedings of SB10 Finland: Sustainable Community BuildingSMART, 160 - 161 .

Haavik, T., Aabrekk, S. A., Mlecnik, E., Cré, J., Kondratenko, I., Paiho, S., Grøn Bjørneboe, M., Hansen, S., van der Have, J. A., Vrijders, J., and Mostad, K. (2012). Guideline: How to develop a business model for One Stop Shop house renovation.

Jakob, M. (2007). The drivers of and barriers to energy efficiency in renovation decisions of singlefamily home-owners. CEPE Working paper series.

Kastner, I., and Stern, P. C. (2015). "Examining the decision-making processes behind household energy investments: A review.” Energy Research \& Social Science, 10, 72-89.

Mahapatra, K., Gustavsson, L., Haavik, T., Aabrekk, S., Svendsen, S., Vanhoutteghem, L., Paiho, S., and Ala-Juusela, M. (2013). "Business models for full service energy renovation of single-family houses in Nordic countries." Applied Energy, 112, 1558-1565.

Mahapatra, K., Gustavsson, L., Haavik, T., Aabrekk, S., Tommerup, H., Svendsen, S., Paiho, S., and Ala-juusela, M. (2011). "Possible financing schemes for one-stop-shop service for sustainable renovation of single-family houses." Nordic Innovation Centre. (Nordic Call on Sustainable 
Renovation NICe; No. 08191 SR).

Marxen, C. K., and Knorborg, R. B. (2011). Metode til planlaegning af vidtgående energirenoveringer af parcelhuse (in Danish).

Mlecnik, E. (2013). "Innovation development for highly energy-efficient housing Opportunities and challenges."

Mlecnik, E., Cré, J., Kondratenko, I., and Hilderson, W. (2011). "Innovations in Very Low energy retrofit projects." In PLEA 2011-27th Conference on Passive and Low Energy Architecture, 601-606.

Mlecnik, E., Kondratenko, I., Cré, J., Vrijders, J., Degraeve, P., van der Have, J. A., Haavik, T., Aabrekk, S. A., Grøn Bjørneboe, M., Hansen, S., Svendsen, S., Stenlund, O., and Paiho, S. (2012). "Collaboration opportunities in advanced housing renovation." Energy Procedia, 13801389.

Mortensen, A., Heiselberg, P. K., and Knudstrup, M.-A. (2015). Energy renovation of Danish singlefamily houses Economy - barrier, motivation and limit.

Risholt, B., and Berker, T. (2013). "Success for energy efficient renovation of dwellings_Learning from private homeowners.” Energy Policy, Elsevier, 61, 1022-1030.

Rogers, E. M. (1962). Diffusion of Innovation. New York (Free Press).

Rogers, E. M. (1995). Diffusion of Innovation. New York (Free Press), New York.

SBi Danish Building Research Institute. (2006). "Be10, Building energy requirement software.”

Statistics Denmark. (2014). "Statistics Denmark." <http://www.statistikbanken.dk/statbank5a/default.asp?w=1920>.

Stieß, I., and Dunkelberg, E. (2013). "Objectives, barriers and occasions for energy efficient refurbishment by private homeowners." Journal of Cleaner Production, 48, 250-259.

Straub, A. (2016). Cohereno: COllaboration for Housing Nearly Zero-Energy RENOvation Publishable Report.

Tommerup, H. M., Vanhoutteghem, L., Svendsen, S., Paiho, S., Ala-juusela, M., Mahapatra, K., Gustavsson, L., and Haavik, T. (2010). "Existing sustainable renovation concepts for singlefamily houses." SB 10 Finland: Sustainable Community - buildingSMART, 160 - 161.

Vanhoutteghem, L., Tommerup, H., Svendsen, S., Paiho, S., Ala-juusela, M., Mahapatra, K., Gustavsson, L., Haavik, T., and Aabrekk, S. (2011). "Full-service concept for energy efficient renovation of single-family houses Extended abstract." Proceedings of SB11 World Sustainable Building Conference, pp. 1323-1330.

Wilson, C., and Dowlatabadi, H. (2007). "Models of decision making and residential energy use." Annual Review of Environment \& Resources, 32(1), 169-203.

Wittchen, K., and SBi. (2004). Vurdering af potentialet for varmebesparelser i eksisterende boliger (in Danish). 
Yin, R. K. (2003). Case study research: Design and methods. Sage Publications, Inc. 